\title{
Effects of Word of Mouth Communication and Perceived Quality on Decision Making Moderated by Gender: Jakarta Blackberry Smartphone Consumer's Perspective
}

\author{
Pantri Heriyati \\ Binus Business School \\ E-Mail: pheriyati@binus.edu \\ Teguh Pratomo Siek \\ Binus Business School \\ E-Mail: teguhps86@yahoo.com
}

\begin{abstract}
BlackBerry smartphones have been very popular among business practitioners and middle-class people in Indonesia. Their popularity may be high because of the rise of mobile internet and social media. The primary objective of the study is to analyze the effect of word of mouth communication among consumers, as well as consumers' perception of product quality, moderated by gender on consumer decision making on BlackBerry smartphones in Indonesia. Insights were collected from young consumers at Jakarta in October 2010. The results reveal that both word of mouth and perceived quality have a positive significant effect on consumer decision making. In addition, there is no significant difference between young male or female respondents with respect to word of mouth communication on consumer decision making or from perceived quality on consumer decision making.
\end{abstract}

Keywords: Consumer Decision Making, Word of Mouth Communication, Perceived Quality, Gender 


\section{INTRODUCTION}

\section{Background}

Research In Motion (RIM) introduced BlackBerry smartphones to the market in 1997. Today, there are forty-six million users around the world. According to six mobile telecommunication operator partners of Research In Motion in Indonesia, there are 1.5 million BlackBerry users in Indonesia (Suryadhi, 2010).

Companies are currently trying to place their products in the consumers' mind via all available channels to generate greater sales. Yet, too much information received may confuse consumers about the type of information that they actually require, that which is really suited to their interests or needs.

Two key works serve as the basis for this study. Kotler and Keller (2009) listed eight ways for companies communicate their products to consumers: through advertising, sales promotion, events and experiences, public relations and publicity, direct marketing, interactive marketing, word of mouth marketing, personal selling. Sernovitz (2009) showed that consumers continually talk about everything that they use and consume, via face-to-face interaction or over media such as the internet. When an idea is transferred to the consumers and they send it to fellow customers, that is a form of real word of mouth communication.

The BlackBerry boom in Indonesia is driven by two main factors (Shubert, 2009). First, the price is perceived of as affordable. The new device costs about $\$ 500$, compared to $\$ 900$ for the new iPhone. Second, it is thought to increase communication accessibility. A survey revealed that eight of ten Indonesians accessed internet via mobile devices (Mahatrisni, 2010).

Gender could be considered an influence on purchase decision making. Kertajaya (2003) argued that the way men and women dealt with the same things are different, which may lead them to behave differently when making purchasing decision, as well. Almost 80 million Indonesian women (approx. 36\% of Indonesian citizens) were potentially a purchase decision maker and responsible for buying the products or services (Mahatrisni, 2010).

\section{Research Questions}

Several investigative research questions have been developed:

1. Does word of mouth communication and perceived quality - which is moderated by gender - have a significant effect on consumer decision making regarding BlackBerry smartphones? 
2. Does word of mouth communication have a significant effect on consumer decision making regarding BlackBerry smartphones?

3. Does perceived quality have a significant effect on consumer decision making regarding BlackBerry smartphones?

4. Does word of mouth communication regarding BlackBerry smartphones have significantly different effects according to gender?

5. Does perceived quality regarding BlackBerry smartphones significantly differ according to gender?

\section{Research Objectives}

The objective of the study is to explore the effect of word of mouth communication among consumers, and consumer's perception over product quality, which is moderated by gender, on consumer decision making for BlackBerry smartphones in Indonesia.

\section{LITERATURE REVIEW}

\section{Word of Mouth Marketing}

Sernovitz (2009) described word of mouth marketing as all about consumers sharing their experiences of products by ways other than direct marketing to consumers. Marketers should give their highest concern to make word of mouth effective. He suggested various categories: (1) Talkers, word of mouth uses people as its mediums; (2) Topics, people as mediums usually share a great topic with others; (3) Tools are the manner that can be used to help people get the message out easily; (4) Taking Part, word of mouth is a dialogue between two entities; (5) Tracking, marketers should track how people talk about products.

\section{Perceived Quality of a Product}

Quality is closely related to satisfaction, which is the gap between a consumer's expectation and the product's perceived performance. Garvin (1984) in Mullins and Walker (2010) described the dimensions of product quality as (1) Performance, (2) Durability, (3) Conformance with Specifications, (4) Features, (5) Reliable, (6) Serviceability, (7) Fit and Finish and (8) Brand Name. 


\section{Gender Differences in Consumer Market}

Kotler and Keller (2009) mentioned that shopping behavior between men and women are different. Women are tend to easily purchase a product without knowing proper informations of it, whereas men are more passive on being interested to a product.

\section{RESEARCH FRAMEWORK}

In order to measure the variables, this research is following variable operationalization procedures (Malhotra and Peterson, 2006). Consumer Decision Making is measured by 5 dimensions: Consumers' Cultural factors, Consumers' Social factors, Personal factors, Consumers' Motivation and Consumers' Perception. Word of Mouth Communication is measured by three dimensions: Talkers, Topics, and Tools. Perceived Quality is measured by four dimensions: Features, Performance, Durability and Serviceability. The research framework can be depicted as follows.

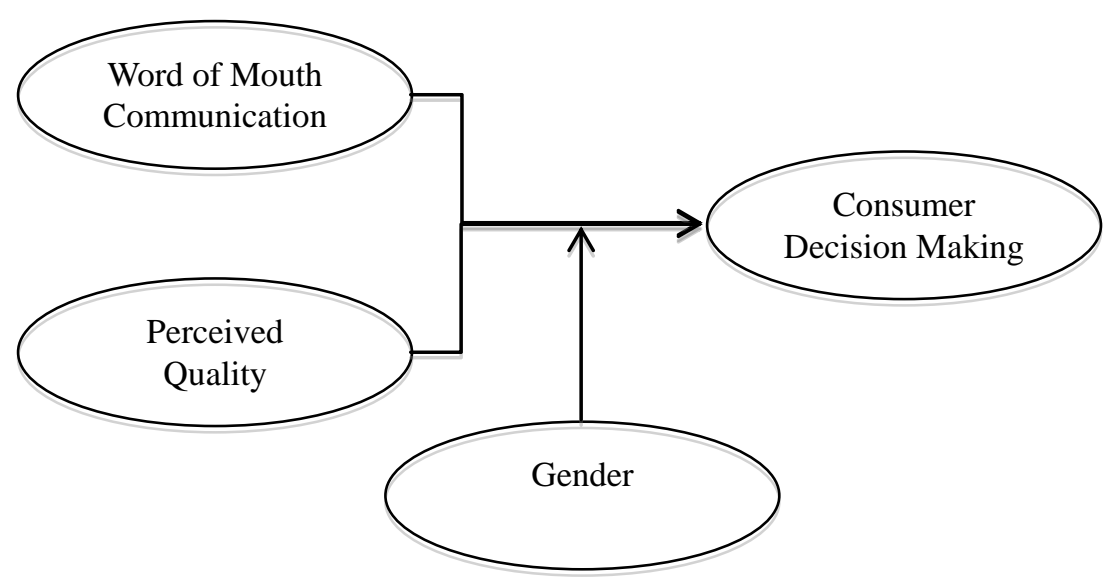

Figure 1 Research Model

\section{Research Methodology}

Two general approaches are used for data collection: literature and desk research to gather secondary data, and questionnaire field surveys to gather primary data. Sampling is based on convenience sampling approach. The targeted samples used on this study are Indonesia's young generation, with the criteria of living in Jakarta and its surrounding cities and having BlackBerry. A pre-test questionnaire was conducted to minimize errors and problems in the main survey study. Data from field research were analyzed for its validity and reliability, and multiple regression analysis was used to test the hypotheses. 


\section{RESEARCH FINDINGS}

Data collected from respondents was analyzed to develop respondent characteristics. This research managed to collect 200 returned questionnaires from 320 distributed. The responses were from 100 females and 100 males, with $71 \%$ in the range of 17 to 24 years of age, and $24 \%$ being 25 to 29 years old. $60 \%$ have a bachelor degree and 55\% have monthly expenses from 1 million to 5 million rupiah.

Reliability tests found that the Cronbach's Alpha for Consumer Decision Making is 0.918 , for Word of Mouth Communication is 0.683 and for Perceived Quality is 0.838 , therefore all variables are considered reliable.

All Corrected Item-Correlation between items have value greater than 0.130 for validity tests, with an exception of PB3 "Public figures as influencers" -item of variable Word of Mouth communication- $(0.092$ as its Corrected Item-Total Correlation). However, opinions from product experts may influence consumer decision making. Therefore, all items are considered valid.

\section{Table 1 ANOVA of Multiple Regression Model}

\begin{tabular}{llccccc}
\hline & Model & Sum of Squares & df & Mean Square & F & Sig. \\
\hline \multirow{3}{*}{1} & Regression & 54.514 & 5 & 10.903 & 40.312 & $.000^{\mathrm{a}}$ \\
\cline { 2 - 7 } & Residual & 52.470 & 194 & .270 & & \\
\cline { 2 - 7 } & Total & 106.984 & 199 & & & \\
\hline
\end{tabular}

Value of $F$ is 40.312 and $p$-value is 0.000 . Because of $p$-value $=0.000<0.10$, there is a significant effect between consumer decision making for BlackBerry smartphones between word of mouth communication and perceived quality, which is moderated by gender. This data analysis also revealed that perceived quality demonstrates a stronger influence on consumer decision making, where the magnitude of the effect is 6.875 , compared to word of mouth communication (magnitude $=$ 2.877). Test of hypotheses are shown in the results of the table below. 
Table 2 Hypotheses Testing Result

\begin{tabular}{|c|c|c|}
\hline Supported Hypotheses & Test Result & Conclusion \\
\hline $\begin{array}{l}\mathrm{H} 1_{\mathrm{a}} \text { : Word of mouth communication and } \\
\text { perceived quality moderated by gender effects } \\
\text { Consumer decision making for BlackBerry } \\
\text { smartphones. }\end{array}$ & $\begin{array}{l}\text { F test: } 40.312 \\
\text { Sig: } 0.000\end{array}$ & $\begin{array}{l}\text { Data is } \\
\text { supporting } \mathrm{H} 1_{\mathrm{a}}\end{array}$ \\
\hline $\begin{array}{l}\mathrm{H} 2_{\mathrm{a}} \text { : Word of mouth communication effects } \\
\text { consumer decision making for BlackBerry } \\
\text { smartphones. }\end{array}$ & $\begin{array}{l}\text { t test: } 2.877 \\
\text { Sig: } 0.004\end{array}$ & $\begin{array}{l}\text { Data is } \\
\text { supporting } \mathrm{H} 2 \text { a }\end{array}$ \\
\hline $\begin{array}{l}\mathrm{H} 3_{\mathrm{a}} \text { : There is a significant effect of perceived } \\
\text { quality on consumer decision making for } \\
\text { BlackBerry smartphones. }\end{array}$ & $\begin{array}{l}\text { t test: } 6.785 \\
\text { Sig: } 0.000\end{array}$ & $\begin{array}{l}\text { Data is } \\
\text { supporting } \mathrm{H} 3 \text { a }\end{array}$ \\
\hline $\begin{array}{l}\mathrm{H} 4_{0} \text { : Word of mouth communication will have } \\
\text { different effect on consumer decision making for } \\
\text { BlackBerry smartphones when moderated by } \\
\text { gender differences. }\end{array}$ & $\begin{array}{l}\text { t test: } 0.743 \\
\text { Sig: } 0.458\end{array}$ & $\begin{array}{l}\text { Data is not } \\
\text { supporting } \mathrm{H} 4 \mathrm{a}\end{array}$ \\
\hline $\begin{array}{l}\mathrm{H} 5_{0} \text { : Perceived quality will have different effects } \\
\text { on consumer decision making for BlackBerry } \\
\text { smartphones when moderated by gender } \\
\text { differences. }\end{array}$ & $\begin{array}{l}\text { t test: } 0.456 \\
\text { Sig: } 0.649\end{array}$ & $\begin{array}{l}\text { Data is not } \\
\text { supporting } \mathrm{H} 5_{\mathrm{a}}\end{array}$ \\
\hline
\end{tabular}

\section{CONCLUSION, MANAGERIAL IMPLICATIONS AND FURTHER RESEARCH SUGGESTIONS}

\section{Conclusions}

Based on the results of this study, the conclusions are as follows.

1. Word of mouth communication and perceived quality, which is moderated by gender, has positive significant effects on consumer decision making for BlackBerry smartphones.

2. The practice of word of mouth communication is one of the factors that influences consumer decision making for BlackBerry smartphones among the young generation in Indonesia.

3. Perceived quality is also found to have a significant effect on consumer decision making for BlackBerry smartphones among respondents.

4. There is no significant different effect between word of mouth communication and perceived quality on consumer decision making for BlackBerry smartphones in male or female respondents. 
5. Perceived quality is more important than word of mouth communication in influencing consumer decision making for BlackBerry smartphones.

\section{Managerial Implications}

Based on the research findings, strategic recommendation are as follows.

1. Sernovitz (2009) suggested marketers feed the talkers with the information that they would like to hear and share.

2. Marketers need to find a topic which can be easily remembered and is buzzworthy (Sernovitz, 2009).

3. Marketers need to find the right tools to send the message (Sernovitz, 2009). With the rise of mobile internet and social media in Indonesia, many companies use social media to gather their loyal customers and feed them the information that they are interested in.

4. Marketers also need to be involved in the conversations among customers (Sernovitz, 2009).

5. Marketers need to listen and learn from any issues shared between customers (Sernovitz, 2009).

6. Research and Development should develop a product that fits with consumers' needs and level of buying power. BlackBerry smartphones were more valuable than any other smartphones because they gave consumers more benefits and smaller costs (Hasanuddin, Kristofel, Mahatrisni, and Winasis, 2010).

7. Marketers should optimize their serviceability in Indonesia.

8. Marketers should empower youth to direct others' minds to their products. Hasanuddin et al. (2011) argued that youth are always more sensitive and more responsive to changes.

\section{Further Research Suggestions}

Further research is suggested by increasing sample size and by adding senior subcultures as target samples in order make the findings more robust. Further research also needs to explore the product attribute preferences (including BlackBerry smartphones). Future research should also compare BlackBerry smartphones with other smartphones to discover the specific reasons why consumers prefer to have BlackBerry smartphones rather than others. Lastly, replication of the research model for other product categories related to brand association may help gain a better insight into gender differences. 


\section{REFERENCES}

Garvin, D. A. (1984). What Does 'Product Quality' Really Mean? Sloan Management Review, 26(1), 25-43.

Hasanuddin, Kristofel, J., Mahatrisni, P. I., and Winasis, N. T. (2010, December 13). Apa pun Operatornya, BlackBerry Ponselnya, Retrieved December 20, 2010, from http://blog.the-marketeers.com/archives/apa-pun-operatornya-blackberryponselnya.html

Hasanuddin, K. J., Mahatrisni, P. T., Winasis, N. T., and Satrio, B. (2011). Anxieties/Desires: 90 Insights for Marketing to Youth, Women, Netizen. Jakarta: Gramedia Pustaka Utama.

Kertajaya, H. (2003). Marketing In Venus, Jakarta: MarkPlus \& Co.

Kotler, P. and Keller, K. L. (2009). Marketing Management (13 ${ }^{\text {th }}$ Ed.). New Jersey: Pearson Education, Inc.

Mahatrisni, P. I. (2010). Memahami Potensi Perempuan Indonesia sebagai Penguasa Market Share (August Ed.). Jakarta: Marketeers.

Malhotra, N. K., and Peterson, M. (2006). Basic Research Marketing: A Decision-Making Approach ( $2^{\text {nd }}$ Ed.). New Jersey: Pearson Education, Inc.

Mullins, J. W., and Walker O. C. Jr. (2010). Marketing Management: A Strategic Decision-Making Approach ( $7^{\text {th }}$ Ed.). New York: McGraw-Hill.

Sernovitz, A. (2009). Word of Mouth Marketing: How Smart Companies Get People talking (Revision and updated Ed.). New York: Kaplan Publishing.

Shubert, A. (2009, December 29). BlackBerry boom in Indonesia, Retrieved August 13 , 2010 , from

http://edition.cnn.com/2009/TECH/12/28/indonesia.blackberry/index.html

Suryadhi, A. (2010, August 13). Rekam Jejak BlackBerry dalam Angka, Retrieved October 25 , 2010 , http://www.detikinet.com/read/2010/08/13/142335/1419915/317/rekam-jejak-bla ckberry-dalam-angka 